\title{
Complete remission of inoperable hepatic and bone metastases due to neuroendocrine pancreatic tumour 3 years after peptide receptor radionucleotide therapy
}

\author{
Paula Soeiro @,${ }^{1}$ Helder Martins @ ${ }^{1}$ Rodolfo Silva, ${ }^{1,2}$ Ana Paula Moreira ${ }^{1,2}$
}

${ }^{1}$ Nuclear Medicine, Centro Hospitalar e Universitário de Coimbra EPE, Coimbra, Portugal ${ }^{2}$ Universidade de Coimbra Instituto de Ciências Nucleares Aplicadas à Saúde, Coimbra, Portugal

Correspondence to Dr Paula Soeiro: paulaspsoeiro@gmail.com

Accepted 16 March 2020

\section{DESCRIPTION}

An 80-year-old Caucasian man, presenting with polymyalgia and asthenia, was incidentally found to have a pancreatic mass. The patient underwent elective body-caudal pancreatectomy and splenectomy, with no major perioperative complications. Histopathological study revealed a $40-\mathrm{mm}$ welldifferentiated nonfuncting neuroendocrine tumour with peripancreatic adipose tissue extension, synaptophysin positive immunostaining, 5 mitoses/10 high power fields and a Ki67 proliferation index of $10 \%$ (G2, pT3N0, stage IIA). Postsurgery laboratory analysis and imaging studies (scintigraphy with $\left[{ }^{111} \mathrm{In}\right]$ In-pentetreotide) confirmed tumour remission.

Two years after the initial diagnosis, disease relapse was documented by a sudden rise in serum chromogranin A $(588.1 \mathrm{ng} / \mathrm{mL}, \mathrm{n}<85)$ and a positive $\left[{ }^{68} \mathrm{Ga}\right] \mathrm{Ga}$-DOTA-NOC $((1,4,7,10$-tetraazacycl ododecane-N,N',N",N'"'-tetraacetic acid)-1-NaI3octreotide) PET/CT scan that showed a $25 \mathrm{~mm}$ high uptake liver lesion in segment II with a maximum standardized uptake value (SUVmax:) of 80.5 . Elective liver metastasectomy was performed and histological examination confirmed a secondary neuroendocrine lesion with a more aggressive Ki67 proliferation index (Ki67 $=15 \%, 7$ mitoses $/ 10$ HPF). Subsequently, a decrease in chromogranin A was observed.

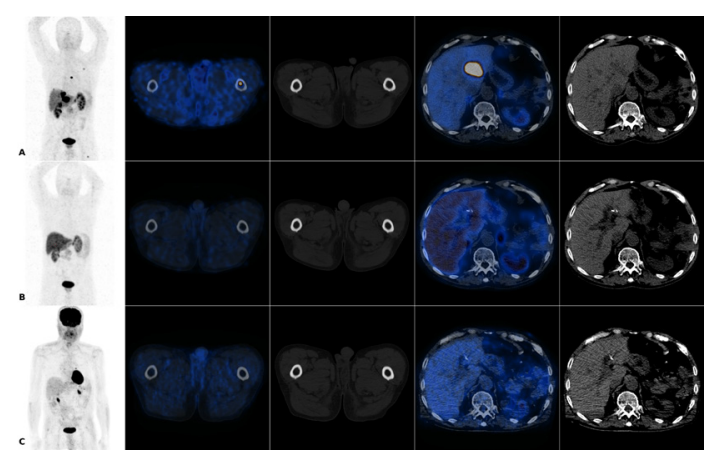

Figure 1 (A) January of $2017\left[{ }^{68} \mathrm{Ga}\right]$ Ga-DOTA-NOC PET/ CT showing multiple hepatic and bone metastases with somatostatin receptors overexpression. (B, C) $2019\left[{ }^{68} \mathrm{Ga}\right]$ Ga-DOTA-NOC and 2-[ $\left[{ }^{18} \mathrm{~F}\right] \mathrm{FDG}$ PET/CTs, respectively, without evidence of differentiated or undifferentiated active disease. DOTA: 1,4,7,10-tetraazacyclododecane$\mathrm{N}, \mathrm{N}^{\prime}, \mathrm{N}^{\prime}$ ",N"'-tetraacetic acid NOC: 1-Nal3-octreotide; PET: positron-emission tomography; 2-[ $\left.{ }^{18} \mathrm{~F}\right]$ FDG: $2-\left[{ }^{18} \mathrm{~F}\right]$ fluoro2-deoxy-D-glucose

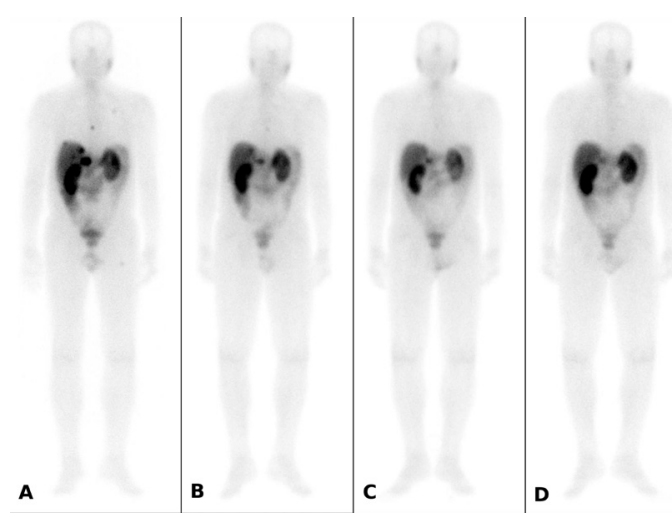

Figure 2 Twenty-four-hour posttherapy [ $\left.{ }^{177} \mathrm{Lu}\right] \mathrm{Lu}$ DOTA-TATE (luteium (1,4,7,10-tetraazacyclododecane$N, N^{\prime}, N^{\prime \prime}, N^{\prime \prime \prime}$-tetraacetic acid)-(Tyr3)-octreotate) scans. (A-D) Scan after first, second, third and fourth cycle of therapy, respectively.

At the fourth-year postdiagnosis reevaluation, an increase in chromogranin A $(394.2 \mathrm{ng} / \mathrm{mL}, \mathrm{n}<85)$ was again noted. A restaging $\left[{ }^{68} \mathrm{Ga}\right] \mathrm{Ga}-\mathrm{DOTA}-\mathrm{NOC}$ $\mathrm{PET} / \mathrm{CT}$ scan (figure $1 \mathrm{~A}$ ) revealed four new hepatic lesions (segments II-SUVmax: 18.5, IV-SUVmax: 16.3, V-SUVmax: 6.2 and VII-SUVmax: 21.3) and bone metastases in the sternum (SUVmax: 1.8) and the second left costal arch (SUVmax: 1.3) with high somatostatin receptor expression. Additionally, a $2-\left[{ }^{18} \mathrm{~F}\right]$ FDG PET/CT scan showed increased glycolytic metabolism in three of the four known hepatic lesions (segments II-SUVmax: 5.4, VSUVmax: 4.1 and VII-SUVmax: 7.6), suggesting a more aggressive disease. Thermoablation of the hepatic lesions was performed and lifelong lanreotide therapy started.

Despite only presenting minor symptoms of abdominal discomfort and asthenia, chromogranin A serum levels kept rising, reaching a peak in February $2017(1210 \mathrm{ng} / \mathrm{mL}, \mathrm{n}<85)$, 5-year postdiagnosis. A $\left[{ }^{68} \mathrm{Ga}\right] \mathrm{Ga}-\mathrm{DOTA}-\mathrm{NOC}$ PET/CT scan documented disease progression with new hepatic (segment III-SUVmax: 6.9) and bone lesions (proximal third of the left femoral diaphysis-SUVmax: 5.2), as well as significant increase in size and uptake of the previously known lesions (segments II-SUVmax: 108.0, IV- SUVmax: 40.1, V-SUVmax :8.9 and VII-SUVmax: 58.3, sternum, SUVmax: 13.1, second left costal archSUVmax: 4.7). The patient was deemed inoperable and proposed for peptide receptor radionuclide therapy (PRRT). 
From March to October 2017, the patient underwent a total of four treatment cycles with $\left[{ }^{177} \mathrm{Lu}\right] \mathrm{Lu}-\mathrm{DOTA}-\mathrm{TATE}$ (figure 2A-D), each with $7.4 \mathrm{GBq}$ (cumulative activity of 29.6 GBq), using Aminoplasmal Hepa $(2500 \mathrm{~mL} /$ cycle) for kidney protection. No haematological or renal toxicity was observed during therapy or follow-up. Clinical improvement in practically all quality of life indicators (as evaluated by EORTC QLQ-C30 questionnaire) was witnessed, particularly overall health status (17\% in the first cycle and $50 \%$ in the fourth cycle), in addition to a $90 \%$ reduction in chromogranin A serum levels.

Two years after PRRT, the patient maintains regular visits to the oncology department with no symptoms or evidence of active disease on both laboratorial and imaging studies, namely $\left[{ }^{68} \mathrm{Ga}\right] \mathrm{Ga}-\mathrm{DOTA}-\mathrm{NOC}$ (figure $1 \mathrm{~B}$ ) and $2-\left[{ }^{18} \mathrm{~F}\right] \mathrm{FDG} \mathrm{PET} / \mathrm{CT}$ (figure $1 \mathrm{C}$ ).

Neuroendocrine neoplasms (NEN) are a very heterogeneous group of diseases, with increasing incidence and prevalence worldwide. ${ }^{1}$ These neoplasms can exhibit different receptors, and expression usually changes during the course of the disease. ${ }^{1-3}$ Screening tests are not readily available yet and patients often present with metastatic disease on initial evaluation. ${ }^{1}$

Multimodality imaging is strongly recommended and nuclear medicine techniques play a key role, namely $\left[{ }^{68} \mathrm{Ga}\right] \mathrm{Ga}-\mathrm{DO}-$ TA-NOC and 2-[ ${ }^{18}$ F]FDG PET/CT. $\left[{ }^{68} \mathrm{Ga}\right]$ Ga-DOTA-NOC PET/ CT evaluates somatostatin receptor expression, overexpressed in many of these neoplasms, and therefore has become indispensable for the diagnosis, staging and restaging, as well as PRRT patient selection. 2- $\left[{ }^{18} \mathrm{~F}\right] \mathrm{FDG}$ PET/CT assesses glycolytic metabolism, a crucial characteristic of aggressive molecular phenotypes, providing independent -prognostic information and also aiding in therapy selection. ${ }^{24}$

PRRT has become a new and useful option in the management of many NEN. ${ }^{1-9}$ Namely, outcome superiority over placebo or SSAs for midgut NEN has been established with high level evidence. Such is not the case, however, for pancreatic NEN, hindering its incorporation into international guidelines. ${ }^{3} 5$ Furthermore, many other radiation free therapies for pancreatic NEN are available and have been approved. ${ }^{5}$

That being said, pancreatic NEN have shown significantly higher response rates to PRRT when compared with other NEN. ${ }^{6}$ Some metastatic or inoperable pancreatic NEN patients are still alive more than 12 years after the beginning of PRRT. ${ }^{8}$ Additionally, some studies imply that repeated $\left[{ }^{177} \mathrm{Lu}\right] \mathrm{Lu}-\mathrm{DO}-$ TATATE treatment cycles, in a so called salvage therapy setting, are feasible, with low incidence of myelodysplastic syndromes and no III/IV grade renal toxicity, and potential overall survival benefit. ${ }^{7}$ On functioning pancreatic NEN, PRRT has been shown to effectively control refractory carcinoid-syndrome symptoms, a very important cause for quality of life reduction. ${ }^{9}$ Nevertheless, in most cases, only a cytostatic effect is observed, increasing progression-free survival. Rarely, tumour burden reduction can be detected, but complete remission is seldom witnessed. ${ }^{3}$

As highlighted in this case, PRRT is an effective therapeutic option with a high safety profile in inoperable metastatic pancreatic NEN that, in some cases, even in aggressive molecular phenotypes, can induce complete remission. In addition, it underscores the importance of a multimodality approach in the management of NEN.

Contributors PS and HM: conception and design, acquisition of data, analysis and interpretation of data, drafting the article. RS and APM: revising it critically for important intellectual content and the final approval of the version published. PS, HM, RS and APM: agreement to be accountable for the article and to ensure that all questions regarding the accuracy or integrity of the article are investigated and resolved.

Funding The authors have not declared a specific grant for this research from any funding agency in the public, commercial or not-for-profit sectors.

Competing interests None declared.

Patient consent for publication Obtained.

Provenance and peer review Not commissioned; externally peer reviewed.

\section{ORCID iDs}

Paula Soeiro http://orcid.org/0000-0002-7692-0343

Helder Martins http://orcid.org/0000-0002-2014-0399

\section{REFERENCES}

1 Bodei L, Mueller-Brand J, Baum RP, et al. The joint IAEA, EANM, and SNMMI practical guidance on peptide receptor radionuclide therapy (PRRNT) in neuroendocrine tumours Eur J Nucl Med Mol Imaging 2013;40:800-16.

2 Strosberg J, El-Haddad G, Wolin E, et al. NETTER-1 Trial Investigators. Phase 3 trial of (177)lu-dotatate for midgut neuroendocrine tumors. N Engl J Med 2017;376:125-35.

3 Falconi M, Eriksson B, Kaltsas G, et al. ENETS consensus guidelines update for the management of patients with functional pancreatic neuroendocrine tumors and nonfunctional pancreatic neuroendocrine tumors. Neuroendocrinology 2016;103:153-71.

4 Panda A, Garg I, Johnson GB, et al. Molecular radionuclide imaging of pancreatic neoplasms. Lancet Gastroenterol Hepatol 2019;4:559-70.

5 Ramage J, Naraev BG, Halfdanarson TR. Peptide receptor radionuclide therapy for patients with advanced pancreatic neuroendocrine tumors. Semin Oncol 2018;45:236-48.

6 Garske-Román U, Sandström M, Fröss Baron K, et al. Prospective observational study of ${ }^{177}$ Lu-DOTA-octreotate therapy in 200 patients with advanced metastasized neuroendocrine tumours (NETs): feasibility and impact of a dosimetry-guided study protocol on outcome and toxicity. Eur J Nucl Med Mol Imaging 2018;45:970-88.

7 van der Zwan WA, Brabander T, Kam BLR, et al. Salvage peptide receptor radionuclide therapy with [ ${ }^{177}$ Lu-DOTA, Tyr $\left.{ }^{3}\right]$ octreotate in patients with bronchial and gastroenteropancreatic neuroendocrine tumours. Eur J Nucl Med Mol Imaging 2019:46:704-17.

8 Gabriel M, Nilica B, Kaiser B, et al. Twelve-Year follow-up after peptide receptor radionuclide therapy. J Nucl Med 2019:60:524-9.

9 Ito T, Lee L, Jensen RT. Carcinoid-syndrome: recent advances, current status and controversies. Curr Opin Endocrinol Diabetes Obes 2018;25:22-35.

\section{Patient's perspective}

I now rarely have pain and feel like a child that can do everything. I wake up every morning and go outside; it seems that I never get tired. Everyone in the Nuclear Medicine Department was very kind to me and I'd like to pay them a visit, even if further treatments aren't needed.

\section{Learning points}

- Gallium-68-labeled somatostatin analogues ( $\left[{ }^{68} \mathrm{Ga}\right] \mathrm{Ga}-\mathrm{DOTA}$ $\mathrm{NOC})$ and fluor 18 - labeled glucose analogue(2-[ $\left.\left.{ }^{18} \mathrm{~F}\right] \mathrm{FDG}\right)$ positron-emission tomography/computed tomography (PET/ $\mathrm{CT}$ ) play a key role in the diagnosis, staging and restaging of neuroendocrine tumours.

- Peptide receptor radionuclide therapy is a safe and effective therapeutic option for the control of inoperable neuroendocrine tumours, with potential quality of life improvement.

- Complete remission with lutetium-177 -labeled somatostatin analogues ([ ${ }^{177}$ Lu]Lu-DOTA-TATE), although rare, is possible in some cases. 
Copyright 2020 BMJ Publishing Group. All rights reserved. For permission to reuse any of this content visit https://www.bmj.com/company/products-services/rights-and-licensing/permissions/

BMJ Case Report Fellows may re-use this article for personal use and teaching without any further permission.

Become a Fellow of BMJ Case Reports today and you can:

- Submit as many cases as you like

- Enjoy fast sympathetic peer review and rapid publication of accepted articles

Access all the published articles

Re-use any of the published material for personal use and teaching without further permission

Customer Service

If you have any further queries about your subscription, please contact our customer services team on +44 (0) 2071111105 or via email at support@bmj.com.

Visit casereports.bmj.com for more articles like this and to become a Fellow 